\title{
PANCREATIC SECRETION AND INTESTINAL DIGESTIBILITY OF AMINO ACIDS IN CHICKEN AT DIFFERENT DIETARY PROTEIN LEVEL AND QUALITY
}

\section{V.I. FISININ, V.G. VERTIPRAKHOV, A.A. GROZINA, L.V. KHASANOVA}

Federal Scientific Center All-Russian Research and Technological Poultry Institute RAS, Federal Agency of Scientific Organizations, 10, ul. Ptitsegradskaya, Sergiev Posad, Moscow Province, 141311 Russia, e-mail Vertiprakhov63@mail.ru, alena_fisinina@mail.ru, lkhasanova@mail.ru ORCID:

Fisinin V.I. orcid.org/0000-0003-0081-6336

Vertiprakhov V.G. orcid.org/0000-0002-3240-7636

Grozina A.A. orcid.org/0000-0002-3088-0454

The authors declare no conflict of interests

Khasanova L.V. orcid.org/0000-0003-4026-4273

Received December 22, 2016

\section{Abstract}

The improvement of feed conversion into the products in poultry production is primarily related to the effectiveness of digestion and assimilation of dietary protein and therefore sets specific requirements on its nutritive value and profile of limiting amino acids, and on the availability of amino acids for absorption and subsequent metabolization. Digestibility and absorbability of amino acids were recently studied in pigs (E.N. Golovko, 2011) and poultry (P. Dalibard et al., 1995; A.E. Yapontsev, 2016) using the concepts of apparent and standardized ileal digestibility. Ileal digestibility is defined as the difference between consumed amounts of amino acids and the unabsorbed residues at the level of distal end of the ileum. Data on ileal digestibility rates allow optimization of dietary protein quality, digestive function and appetite (V. Ryadchikov et al., 2010). Our earlier studies showed that secretory function of the pancreas in adult chicken and broiler chicks can adjust to the changes in dietary amino acid balance; when dietary level of limiting amino acid (lysine) reached the recommended level the enzymatic activities in pancreatic juice grew substantially (Ts.Zh. Batoev, et al., 1990; V.G. Vertiprakhov, 2015). In this study we have experimentally found differences between enzymatic activities in pancreatic juice and ileal chymus and ileal amino acid digestibility in chronically fistulated chickens which were fed diets of different protein levels. Control diet was standard wheat-based, and experimental diet was supplemented with poorly hydrolysable ingredients (wheat bran, sunflower cake) contained lower levels of crude protein and energy. When chickens were fed with experimental diet instead of control one the decreases in proteolytic activity in pancreatic juice by 22-36 \% and in ileal chymus by $34 \%$ (compared to control) were found. Data on ileal digestibility of amino acids showed that intestinal digestion of amino acids is more effective at higher dietary protein level; this effect can be related to the increase in enzymatic activities of digestive juices in response to the increase in dietary protein, and to the concomitant improvement in feed palatability. ids, chicken

Keywords: exocrine pancreatic function, pancreatic enzymes, ileal chymus, amino ac-

In the digestive tract, food is converted into substances able to be absorbed in the body, which ultimately determines the metabolic processes. Increasing the conversion of feed to livestock products, including physiological methods, is relevant. Effective use of fodder proteins by the bird puts forward certain requirements, i.e. usefulness, the optimal ratio of the amino acids that limit productivity, accessibility to absorption and involvement in metabolic processes. In recent years, there has been enough papers to consider amino acid assimilation in digestion of pigs [1-3] and poultry [4, 5]. For this purpose, methods are proposed that allow one to determine the apparent and true ileal digestibility of amino acids. It is known [1] that the traditional ways of determining the availability of amino acids in the terminal part of the digestive tract do not allow obtaining reliable indices because of significant qualitative and quantitative changes in the composition of nitrogen-containing substances by microorganisms 
inhabiting the large intestine. Estimation of the availability of amino acids based on the difference in their input with food and undigested amount in ileum is performed on ileostomized animals by ileal method. This method showed that the animal appetite depends primarily on the balance of diets for essential amino acids [6].

Digestive enzymes of the small intestine adapt to the source of the consumed protein [7]. Previously, we found that the secretory function of the pancreas of broilers and hens respond to the balance of amino acids in the diet, and when the limiting amino acid is introduced to the norm of demand, the enzymatic activity of pancreatic juice significantly increases $[8,9]$. In the study of microbial communities, their composition correlated to metabolism of essential amino acids in laying hens [10]. However, we do not know the papers considering a relationship between the availability of amino acids and the food taste.

In this paper, using the ileal method, we first showed that the assimilation of amino acids in the digestive tract depends on the secretory function of the pancreas, which adequately responds to the quality of protein nutrition.

Our goal was to study, in physiological experiment, the activity of enzymes in pancreatic juice and chyme of the ileum, as well as the content of amino acids in the ileum of hens when using compound feeds different in protein levels.

Technique. Pancreas secretion was studied in a chronic experiment on two fistulated 7-8-month old Leghorn hens according to C.Zh. Batoev et al. [11]. For the first 10 days the birds were fed with a control compound feed corresponding to zootechnical norms, and the next 10 days the compound feed containing hardly hydrolyzable components (wheat middling, sunflower oilcake) was given. Experiments started in the morning on an empty stomach. After the first $30 \mathrm{~min}$ the hens received $30 \mathrm{~g}$ of compound feed, and then pancreatic juice was collected for 2.5 hours with 30 -min intervals. In the portions of the secret, the volume of juice and the activity of amylase, proteases and lipase were determined.

The enzymatic activity and the amino acid composition of the chyme were analyzed in three Leghorn hens aged 30-40 days with T-shaped cannula implanted in the ileum at $10-15 \mathrm{~cm}$ distance from the thick intestine. The experiment was started in the morning on an empty stomach, the birds received $30 \mathrm{~g}$ of compound feed, and within an hour the intestine chyme was collected. The sample was centrifuged for $5 \mathrm{~min}$ at $5,000 \mathrm{rpm}$, and the supernatant was diluted (1:50) with Ringer solution.

Activity of amylase estimated by Smith-Roy-Ugolov method [12] as the amount of starch (mg per ml juice) cleaved for a minute, and proteolytic activity expressed as the amount of casein $(\mathrm{mg}$ per $\mathrm{ml})$ hydrolyzed for a minute were recorded at $\lambda=670 \mathrm{~nm}$ and $\lambda=450$, respectively, on a photometer KFK-3 (OOO Zagorsk Optical and Mechanical Plant, Russia) [13], the lipase activity was assayed on a semi-automatic biochemical analyzer BS3000P (SINNOWA, China) using veterinary diagnostic reagent kit for the determination of blood lipase in animals (DIAKON-VET, Russia).

Free amino acids in the ileal chyme was determined by ion exchange chromatography with post-column derivatization with a ninhydrin reagent and detection at $\lambda=570 \mathrm{~nm}$ (for proline $\lambda=440 \mathrm{~nm}$ ). The analysis was performed using a high performance liquid chromatography (HPLC) YL 9100 HPLC System (Young Lin Instrument Co., Ltd, Korea) consisting of a YL9110 gradient pump, YL9101 vacuum degasser, YL9120 UV/VIS detector, YL9150 autosampler (postcolumn derivatizer Pinnacle PCX, ion exchange column $\mathrm{Na}^{+}$ $4.0 \times 150 \mathrm{~mm}, 5 \mu \mathrm{m}$, pre-column $\mathrm{Na}^{+} 3.0 \times 20 \mathrm{~mm}, 5 \mathrm{~m}$, Pickering Laboratories, Inc., USA).

The mean $(X)$ and standard errors of the mean $(x)$ are shown. The sig- 
nificance of differences was evaluated by Student's $t$-test. Differences were considered statistically significant at $\mathrm{P} \leq 0.05$.

\section{Feed composition}

\begin{tabular}{l|ccc}
\hline \multirow{2}{*}{ Ingredients } & \multicolumn{2}{c}{ Content, \% } \\
\cline { 2 - 3 } \multicolumn{1}{c}{ Wheat } & control & experimental \\
Barley & 43.6 & 44.7 \\
Wheat middling & 45.1 & 22.9 \\
Soy bean meal & 0 & 13.6 \\
Sunflower cake & 9.4 & 0 \\
Lime (36 \%) & 4.5 & 11.3 \\
Monocalcium phosphate & 2.3 & 2.4 \\
Maize gluten & 1.1 & 0.9 \\
Fish flour & 1.0 & 1.0 \\
Sunflower oil & 1.0 & 1.0 \\
Salt & 1.0 & 1.0 \\
Sodium sulfate & 0.25 & 0.25 \\
Mixture: & 0.196 & 0.205 \\
$\quad$ mineral 0.08 \% & & 0.080 \\
$\quad$ vitamin 0.02 \% & 0.080 & 0.020 \\
Methionine & 0.020 & 0.091 \\
& 0.066 & \\
Metabolic energy, kcal & o f f o d d e r \\
Crude fat, \% & 270.0 & 260.0 \\
Crude fiber, \% & 3.57 & 4.98 \\
Crude protein, \% & 5.0 & 6.0 \\
Calcium, \% & 16.0 & 14.0 \\
Phosphorus, \% & 1.20 & 0.70 \\
\hline
\end{tabular}

Results. The applied technique of collecting pancreatic juice is unique due to specific morphology of digestive tract in birds, with three pancreas ducts and two bile ducts joined to duodenum in the same place. When ileostomy, a fragment of the intestine (an isolated sac) is cut out, to which the main pancreatic duct is placed, and the intestine fragments are joined "end-to-end". The technique allows to obtain pancreatic juice during experiments, and in other the time juice is directed to the external anastomosis in the intestine. After the recovery period, the bird can be used for a long time.

Composition of the compound feed used is shown in Table 1. Our experiments showed the exocrine function of chicken pancreas to be clearly adapted to the fodder (Table 2), and this was mainly due to a change in enzymatic activity, and not the amount of pancreatic juice.

2. Exocrine function of the pancreas in Leghorn hens depending on the consumed feed $(n=20, X \pm x)$

\begin{tabular}{|c|c|c|c|c|}
\hline \multirow{2}{*}{ Parameter } & \multicolumn{2}{|c|}{ Hen 1} & \multicolumn{2}{|c|}{ Hen 2} \\
\hline & control & experiment & control & experiment \\
\hline $\begin{array}{l}\text { The amount of pancreatic juice per experiment, } \mathrm{ml} \\
\text { Activity: }\end{array}$ & $5.4 \pm 0.49$ & $6.8 \pm 0.50$ & $7.0 \pm 0.31$ & $8.8 \pm 1.15$ \\
\hline amylase, $\mathrm{mg} \cdot \mathrm{ml}^{-1} \cdot \min ^{-1}$ & $3400 \pm 240.8$ & $3534 \pm 187.5$ & $1984 \pm 86.1$ & $2800 \pm 530.7$ \\
\hline lipase, U/I & $7792 \pm 396.5$ & $9824 \pm 498.9^{*}$ & $11515 \pm 768.9$ & $13518 \pm 74.6^{*}$ \\
\hline protease, $\mathrm{mg} \cdot \mathrm{ml}^{-1} \cdot \min ^{-1}$ & $257 \pm 18.4$ & $200 \pm 14.4 *$ & $164 \pm 11.4$ & $105 \pm 5.3^{*}$ \\
\hline Amylase:protease & $13: 1$ & $18: 1$ & $12: 1$ & 27:1 \\
\hline
\end{tabular}

The secretion of the great amount of enzymes necessary for digesting incoming food (and, as a consequence, an increase in their concentration in pancreatic juice) seems to be the most perfect type of specific enzymatic adaptations of the pancreas. An increase in the volume of secreted juice, a less effective and less specific mechanism, is used if specific adaptation is impossible for some reasons. In this, the amount of enzymes may not correspond to the diet so strictly. Adaptation of pancreatic enzymes can be studied in more detail by analyzing the dynamics of juice and enzyme secretion after ingestion [14, 15].

In our experiment there was a change in the activity of two enzymes, lipase and protease. In receiving experimental compound feed, lipase activity was $26.1 \%$ $(\mathrm{P} \leq 0.05)$ higher in hen 1 and $17.4 \%(\mathrm{P} \leq 0.05)$ higher hen 2. On the contrary, proteolytic activity, with the replacement of compound feed containing $16 \%$ crude proteins for those with $14 \%$ crude proteins, decreased by $22.2 \%$ and $36.0 \%$ for hen 1 and hen 2, respectively, compared to the control. The amylase:protease ratio also significantly changed and amounted to $12-13: 1$ in control period reaching up to 1827:1 in experimental period. This indicates the adaptation of enzymatic activity to the low-protein diet.

Thus, when substituting more nutritious and energetically balanced feed 
for low-protein diet with $10 \mathrm{kcal}$ less metabolic energy, the exocrine function of the pancreas responded by $22-36 \%$ decrease in proteolytic activity and 17-26\% increase in lipase activity as compared to control. This was due to the addition of wheat middling (13.6\%), sunflower oilcake $(11.3 \%)$, barley $(22.9 \%)$, which are difficult to hydrolyze, and $39.4 \%$ more fat (see Table. 1). And the most significant differences occurred during the first hours after feeding because of the complex reflex regulation of pancreatic secretion and, thus, due to the fodder taste [14]. Given the fact that the pancreas is one of the central organs of the digestive system and its function correlates with the digestibility of the fodder [16], the observed changes should suggest a decrease in the digestion efficiency of the dietary protein.

Activity of digestive enzymes in chyme of ileum, the main part of which are pancreatic enzymes, adapted to the nutrition (Table 3).

3. Enzymatic activity in chyme of the ileum in Leghorn hens depending on the consumed feed (average for 3 hens, $n=20, X \pm x$ )

\begin{tabular}{|c|c|c|c|}
\hline \multirow{2}{*}{ Indicators } & \multicolumn{2}{|c|}{ Compound feed } & \multirow{2}{*}{ Vs. control, \% } \\
\hline & control & experimental & \\
\hline Amylase activity, $\mathrm{mg} \cdot \mathrm{ml}^{-1} \cdot \mathrm{min}^{-1}$ & $269 \pm 44.1$ & $167 \pm 16.4^{*}$ & 62.1 \\
\hline Lipase activity, U/I & $2479 \pm 293.3$ & $2435 \pm 185.8$ & 98.2 \\
\hline Protease activity, $\mathrm{mg} \cdot \mathrm{ml}^{-1} \cdot \min ^{-1}$ & $21.0 \pm 1.39$ & $13.8 \pm 1.55^{*}$ & 65.7 \\
\hline * Differences with control are stati & $\leq 0.05$ & & \\
\hline
\end{tabular}

The most significant changes were in the amylolytic and proteolytic after the replacement of compound feed containing $16.0 \%$ of crude proteins for that with a reduced crude protein content $(14.0 \%)$. In this, the amylase activity was $37.9 \%$ lower, and proteolytic activity was $34.3 \%$ lower. The substitution of the control compound for the changed feed (see Table 1) did not affect lipase activity, despite the fact that the amount of fat in the fodders was somewhat different.

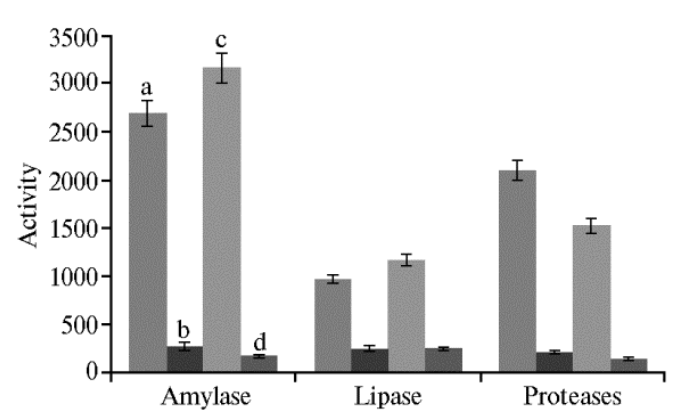

Amylolitic $\left(\mathrm{mg} \cdot \mathrm{ml}^{-1} \cdot \mathrm{min}^{-1}\right)$, lipolytic $(\mathrm{U} / \mathrm{l})$ and proteolytic $\left(\mathrm{mg} \cdot \mathrm{ml}^{-1} \cdot \mathrm{min}^{-1}\right)$ activity in pancreatic juice (a - control, c - experiment) and duodenal chyme (b - control, $d$ - experiment) in Leghorn hens when using different compound feeds. For a description of the composition of the fodder in control and experiment, see Table 1 . The average values $(n=20)$ for 3 hens are given. The shown indices are 10 times decreased for lipase activity and 10 times increased for proteases. by $17.5 \%$, and in intestinal chyme decreased by $37.9 \%$, indicating dilution of duodenal chyme by other digestive juices, water, etc., or the formation of an enzyme-substrate complex in the cleavage of carbohydrates. This can be explained by experimental fodder composition with a higher content of nonstarchy polysaccharides compared to control, which interfere with the interaction of digestive enzymes and substrates, and increase chyme viscosity $[17,18]$.

The activity of proteolytic enzymes in pancreatic juice and duodenal 
chyme varied simultaneously, decreasing with the use of modified compound fodder (experiment). The ratio of lipase activity in pancreatic juice and duodenal chyme was the lowest (4-5:1), which is due to the relatively high activity of the enzyme in the intestine, since bile secreted into intestine along with pancreatic juice is the most powerful stimulant and fat emulsifier [19].

4. Amino acid composition of feed and chyme of the ileum in three Leghorn hens depending on the consumed feed (averaged samples)

\begin{tabular}{|c|c|c|c|c|c|c|}
\hline \multirow{2}{*}{ Amino acid } & \multicolumn{2}{|c|}{ In compound feed, $\%$} & \multirow{2}{*}{ Vs. control, \% } & \multicolumn{2}{|c|}{ In chyme, $\%$} & \multirow{2}{*}{ Vs. control, $\%$} \\
\hline & control & experiment & & control & experiment & \\
\hline Cysteic acid & 0 & 0 & & 0.014 & 0.011 & 78.6 \\
\hline Aspartic acid & 1.24 & 0.88 & 70.9 & 0.008 & 0.029 & 362.5 \\
\hline Threonine & 0.55 & 0.45 & 81.8 & 0.015 & 0.047 & 313.3 \\
\hline Serine & 0.69 & 0.60 & 86.9 & 0.007 & 0.026 & 371.4 \\
\hline Glutamic & 3.17 & 3.15 & 99.4 & 0.025 & 0.057 & 228.0 \\
\hline Proline & 1.18 & 1.17 & 99.1 & 0.015 & 0.037 & 246.7 \\
\hline Glicine & 0.68 & 0.66 & 97.0 & 0.015 & 0.036 & 240.0 \\
\hline Alanine & 0.75 & 0.70 & 93.3 & 0.026 & 0.025 & 96.1 \\
\hline Cisteine & 0.30 & 0.28 & 93.3 & 0.011 & 0.005 & 45.5 \\
\hline Valine & 0.75 & 0.67 & 89.3 & 0.017 & 0.034 & 200.0 \\
\hline Methionine & 0.42 & 0.38 & 90.5 & 0.009 & 0.011 & 122.2 \\
\hline Isoleucine & 0.61 & 0.51 & 83.6 & 0.012 & 0.027 & 225.0 \\
\hline Leucine & 1.20 & 1.10 & 91.7 & 0.023 & 0.039 & 169.6 \\
\hline Tyrosine & 0.49 & 0.44 & 89.8 & 0.013 & 0.033 & 253.8 \\
\hline Phenylalanine & 0.77 & 0.65 & 84.4 & 0.017 & 0.031 & 182.3 \\
\hline Lysin & 0.94 & 1.06 & 112.8 & 0.025 & 0.032 & 128.0 \\
\hline Histidine & 0.43 & 0.34 & 79.1 & 0.006 & 0.016 & 266.7 \\
\hline Arginine & 0.92 & 0.73 & 79.3 & 0.007 & 0.021 & 300.0 \\
\hline Total & 15.10 & 13.77 & & 0.270 & 0.520 & \\
\hline
\end{tabular}

The amino acid composition of chyme in the ileum of chickens (Table 4) showed that the amount of proteins in the compound feeds varied by $1.33 \%$. Only for lysine the parameters for compound feed in the experiment exceeded the control ones by $12.8 \%$, and for the remaining amino acids a decrease was observed. When comparing amount of the basic amino acids to the norms recommended for laying hens [20], it can be noted that the control feed and the main ingredients of the experiment feed corresponded to these norms. In our experiment, during consumption of feed with hardly hydrolyzable components, the sum of amino acids in the chyme of the ileum increased, compared to the control period, to $3.77 \%$ of the number of amino acids in the feed. In control period of feeding, $1.79 \%$ of the amino acids in ileum remained undigested, which is almost $2 \%$ less than during the experimental period. There is evidence that when the proportion of crude proteins in the diet decreases, the excretion of total nitrogen decreases as well, mainly due to an increase in the ileal digestibility of amino acids [21]. However, when using protein from a single source, the amount of protein does not affect the assimilation of amino acids in the ileum [22].

In our work, we was not motivated to establish the true availability of amino acids, but tried to connect the secretory function of the pancreas with assimilation of amino acids at different content and quality of proteins in the diet in order to understand the causes that affect the availability of amino acids for poultry. The question of the true availability of amino acids remains controversial which is caused by difficulties in determining endogenous amino acids, including limitations of almost all existing methods for their detection [2]. However, a comprehensive study of digestion processes on fistulated poultry, in our opinion, makes it possible to clarify and consider the processes of protein digestion and absorption, taking into account the neuro-humoral regulation. The advantage of this approach, laid down by academician I.P. Pavlov's in the physiology of digestion, is due to the opportunity to consider processes not fragmentarily [23], but in a body as a whole.

So, the feed most balanced in protein composition positively affects the 
secretory function of the pancreas, stimulates the appetite of the poultry and contributes to an increase in ileal digestibility of amino acids.

\section{RE F E R E N C ES}

1. Golovko E.N., Tarabrin I.V., Ryad chikov V.G., O marov M.O. Problemy biologii produktivnykh zhivotnykh, 2009, 1: 31-48 (in Russ.).

2. O marov M.O., S les a reva O.A., Os manova S.O. Problemy biologii produktivnykh zhivotnykh, 2016, 3: 82-91 (in Russ.).

3. Niyazov N.S.-A., Rodionova O.N., P'yankova E.V. Problemy biologii produktivnykh zhivotnykh, 2016, 4: 81-89 (in Russ.).

4. Dalibard P., Pa illard E. Use of the digestible amino acid concept in formulating diets for poultry. Anim. Feed Sci. Technol., 1995, 53: 189-204 (doi: 10.1016/0377-8401(95)02010-W).

5. Y a p o n t s e v A.E. Ptitsevodstvo, 2016, 2: 35-37 (in Russ.).

6. Ren L.Q., Zhao F., Tan H.Z., Zhao J.T., Zhang J.Z., Zhang H. F. Effects of dietary protein source on the digestive enzyme activities and electrolyte composition in the small intestinal fluid of chickens. Poultry Sci., 2012, 91(7): 1641-1646 (doi: 10.3382/ps.201102081).

7. Ryadchikov V., O marov M., Polezhaev S. Zhivotnovodstvo Rossii, 2010, 2: 49-52 (in Russ.).

8. B at o e v Ts.Zh., Ve rti p ra k hov V.G. Sibirskii vestnik sel'skokhozyaistvennoi nauki, 1990, 6: 51-53 (in Russ.).

9. Vertiprakhov V.G. Pancreatic exocrine function in hens with addition of lysine and methionine to their ration. Russian Agricultural Sciences, 2015, 41(2-3): 171-174.

10. N i k o n o v I.N. Zootekhniya, 2012, 11: 27-28 (in Russ.).

11. B a t o e v Ts.Zh., B a t o e v S.Ts. Fiziologicheskii zhurnal SSSR, 1970, 56(12): 1867-1868 (in Russ.).

12. M e ri n a -G lu z k i n a V.M. Laboratornoe delo, 1965, 3: 142-146 (in Russ.).

13. B a t o e v Ts.Zh. Sbornik nauchnykh trudov Buryatskogo SKHI (Ulan-Ude), 1971, 25: 122-126 (in Russ.).

14. Vertip rakhov V.G., Svitki n V.S. Rossiiskaya sel'skokhozyaistvennaya nauka, 2017, 1: 39-42 (in Russ.).

15. Vertiprakhov V.G., Egorov I.A. The influence of feed intake and conditioned reflex on exocrine pancreatic function in broiler chicks. Open Journal of Animal Sciences, 2016, 6(4): 298-303 (doi: 10.4236/ojas. 2016.64034).

16. S h p i l e v a G.S. Issledovaniya po morfologii i fiziologii zhivotnykh (sbornik nauchnnykh trudov Dal'GAU, Blagoveshchensk), 2002, 14: 3-7 (in Russ.).

17. A m e rak h A., P e ro n A. Kombikorma, 2013, 12: 73-75 (in Russ.).

18. Il'i na L.A., Yild irim E.A., Nikonov I.N., Filippova V.A., Laptev G.Yu., Novikova N.I., Grozina A.A., Le nkova T.N., M a nu k y n V.A., Fis in in V.I., Egorov I.A. Taxons of chicken cecum microbiom are abundant, and influenced by the combined feed composition and decreased metabolizable energy. Agricultural Biology, 2015, 50(6): 817-824 (doi: 10.15389/agrobiology.2015.6.817eng) (in Engl.).

19. B a t o e v Ts.Zh. Fiziologiya pishchevareniya ptits [Physiology of digestion in birds]. Ulan-Ude, 2001 (in Russ.).

20. Rukovodstvo po optimizatsii retseptov kombikormov dlya sel'skokhozyaistvennoi ptitsy /Pod redaktsiei V.I. Fisinina, I.A. Egorova, T.N. Lenkovoi et al. [Guidelines for the optimization of recipes for mixed fodders in poultry. V.I. Fisinin, I.A. Egorova, T.N. Lenkova et al. (eds.)]. Sergiev Posad, 2014: 6 (in Russ.).

21. Ot to E.R., Yok o y a m a M., Ku P.K., A mes N.K., Trott i e r N.L. Nitrogen balance and ileal amino acid digestibility in growing pigs fed diets reduced in protein concentration. $J$. Anim. Sci., 2003, 81(7): 1743-1753 (doi: 10.2527/2003.8171743x).

22. Donkoh A., Moughan P.J. The effect of dietary crude protein content on apparent and true ileal nitrogen and amino acid digestibilities. Br. J. Nutr., 1994, 72(1): 59-68 (doi: 10.1079/BJN19940009).

23. De nbow M.D. Gastrointestinal anatomy and physiology. In: Sturkie's avian physiology. C.G. Scanes (ed.). Elsevier, 2015: 337-367. 